University of Louisville

ThinkIR: The University of Louisville's Institutional Repository

Electronic Theses and Dissertations

\title{
$5-1911$
}

\section{The school garden from an educational view point.}

Emilie Yunker

University of Louisville

Follow this and additional works at: https://ir.library.louisville.edu/etd

\section{Recommended Citation}

Yunker, Emilie, "The school garden from an educational view point." (1911). Electronic Theses and Dissertations. Paper 1629.

https://doi.org/10.18297/etd/1629

This Master's Thesis is brought to you for free and open access by ThinkIR: The University of Louisville's Institutional Repository. It has been accepted for inclusion in Electronic Theses and Dissertations by an authorized administrator of ThinkIR: The University of Louisville's Institutional Repository. This title appears here courtesy of the author, who has retained all other copyrights. For more information, please contact thinkir@louisville.edu. 
"THE SCHOOI GARDEN FRON AN BDUCATIONAI VIEN POINT." A THESIS
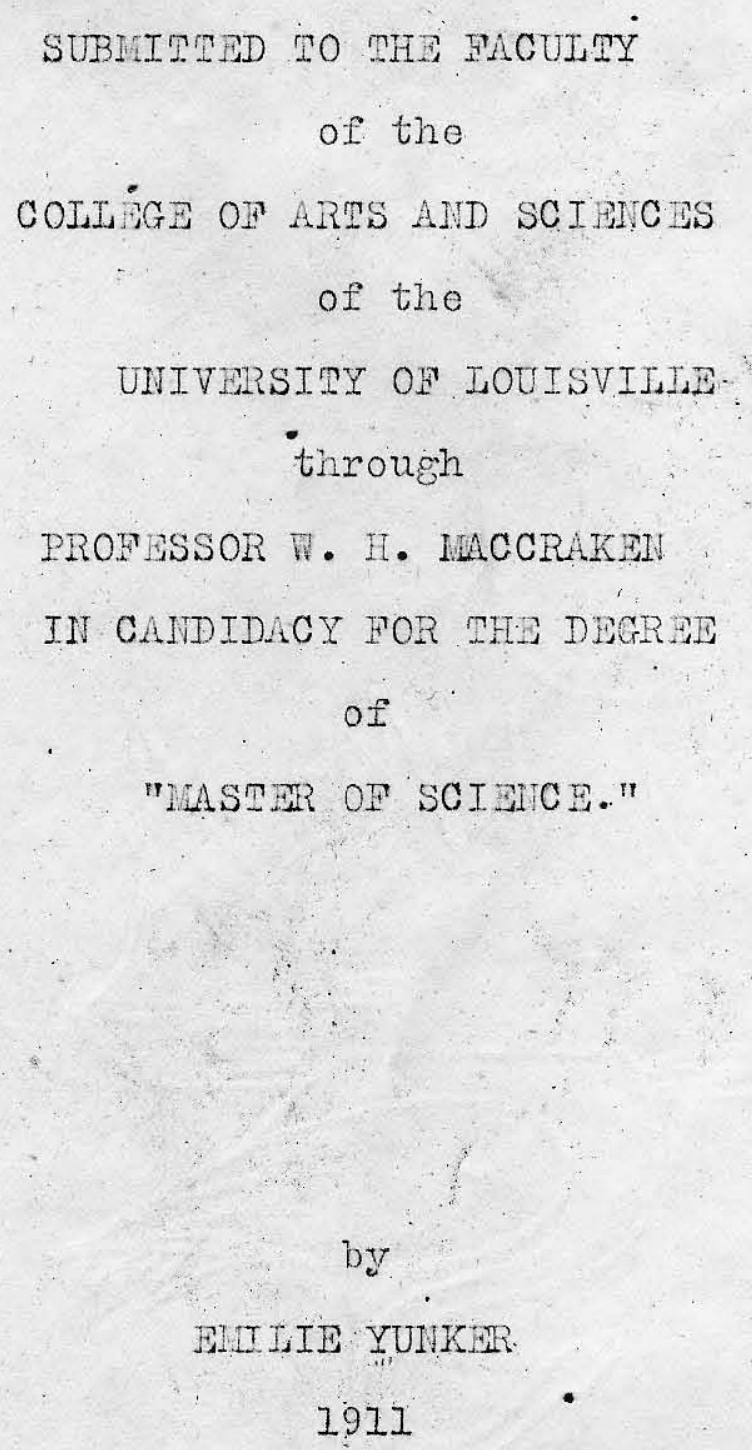


\section{THE SCHOOL GARDEN}

\section{From}

\section{An Educational -Viewpoint-}

\section{$=== \pm==$}

\section{The School Garden=}

"School gardens, are not intended to create gardenersc or farmers but to afford the growing boy or girl an opportunity for many dided developments."

In the sahool garden the children are taught by one who can inspire them with a love not only for plants, but for everything else that has life and grows, to take care of trees, lawns, flowers, vegetables and such things planted with their own hands. It is a place where the plants together with their friends and enemies have an intimate relation to the child personally; where the lessons are far more vital than anything he can get from books, where the child learns the wonderful story of the plant; the life in the seed, the function of root, leaf, stem, flowers and seed by the closest scrutiny of which he is capable.

Says Celia Thaxter in, "An Islana Garden": "Of all the wonderful things in the wonderful universe of God, nothing seems to me more surprising than the.planting of a seed in the black eartin and the result thereof. Take a Poppy seed for instance, it 11 es in your palm the merest atom of matter, hardly visible, a speck, a pin's point in bulk, but wituin it is imprisoned a spirit of beauty ineffable, whicn w111 break its bonds and emerge from the dark ground and blossom in a splendor so dazzling as to baffle all poprs of description. The 
Genie in the Arablan tale are not half so astonishing".

In the school garden, the child is shown how to help or hinder nature, increasing or lessening the yleld of his own crops, thereby early learning a veluabie lesson-"As he sows, so shall he also reap". Here he must use the sun's heat and light together witis alr, water and eartis. He must husband all the netural forces and learn to master them. By closely observing the work of one species of worm in constructing his burrow, boring a short distance, then lining it,

a. famous engineer learned to consiruct tunnels under water, where before this was deemed utterly impossible. There are many difficult problems for which as yet there have been no solution, but which will some day be solved by those who learn of nature and her forces. Nature says, "Watch, learn how I work".

-Purpose of the School Garden$====$

Froebel in his, Menschen-Erzlehung, says-"Lead chlldren early to think, tris is fundamental in child training". To train them early to work and industry seemed so obvious to him as to need no statement. He adds, "The child that has been led to think, is it not led at the same time to industry and diligence-to all virtues of home and country?" Let us hear and heed this and not allow any child to grow up thoughtless and $1 d l_{0}$.

The school garden affords ons of the best opportunities for the development of the child where he is trained to think and work. When once a child is trained along the lines of activity, he'll unconsciously form habits of industry which are sure to be carried into the school room where the most perplexing problems are solved, and later on into 
the larger school of $11 f e$.

Whatever the special purpose of the school garden, this should be kept in mind: the far-reaching influence that will pervade a neigisborhood from a successful garden, will so insplre pupils and parents as to encourage them to make gardens at home, where plants may spring up as restful, cheerful bits of color. Its influence should be far reaching. It wass't long before a mutual interest was established between pupils and noighbors at the Normal school, after a hardy garden,quite unheard of in that part of the City, had been eBtablished. Intelligent questions were asked the children about their plants. Exchanges were made, marigolds and pepper seedlings were offered for live-forever, seeds of the castor bean for a clematis, and a Dorothy Perkins Rambler. Hundreds of Maximilian Sunflowers and other hardy plants found their way to home gardens and several charitable institutions, the members of the City Beautiful Club of the Normal School, helping to plant them.

These children were surprisingly successful with their first attempt at raising California Privet from cuttings made at school in the Fall, and were able to distribute enough plants this Spring among the nighbors to make three hedges;all were grown in a hot bed of their own making.

\section{-Why Barly Interests Should Be Enlisted-}

Gardening must be begun early. "Give the child large interests and give them early". If habits of indolence and carelessness have been formed and viclous tagtes have been allowed to develop, the reformation will be diffloult, and most assurediy fragmentary and unsatisfactory. Besides we know that it is better to form than to 
reform a boy.

This work is so simple, so primltive, that it appeals to every normal child. Long before he can read in a book, the child can begin to read and interpret nature and learn to do many tnings which will make him dependent upon no one.

It acts as a stimulus. The task will seem light to a boy if he knows that upon its succéssful accomplishment, he will be permitted to work in the garden. In fact,he doesn't consider it work at all. An indolent and otherwise troublesome boy was encouraged in this way by being allowed to work each day, provided he first solved the problems given him. Though simple at flrst, these were gradually increased unt11 he could master anything set before him. It was not long before he was one of the brightest and best in his class. The children who helped clean up a vacant lot, made it not only sanitary but attractivea joy to the passerby and a source of constant pleasure to the neighbors. The flowers were beaut1ful; the radishes, beans and lettuce fresh and crisp. The children said, "they were the best we have ever eaten." Their efforts were crowned with success. They had actually achieved something. Not one consldered it work, to them it was play. When the Iote was sold and a house bullt upon it, no one regretted it more than the children. Said one little fellow, "we can"t have any. more fun now".

- These boys had played there before, but had become such a nuisance to the neighbors by breaking windows with their ball playing, jumping the fence and breaking.the flowers, that the owner of the lot was constantly being appealed to with the request that a stop be put to 
the annoyance. After the garden was established not one complaint was made against the children. No more trespassing, no more destruction, and no more vandalism.

The children in the kindergarten should have their garden where they can $d_{i}$ and delve to their heart's content and sow seeds of plants which mature quickly. A friend when asked why she was sack an enthusiastic gardner said: "I had two Grand-mothers when I was a child, who gave me seeds from their gardens. They taught me gardening and on my fifth birthday, presented me with a set of tools. The love of gardening increased as I grew older until now it is almost a passion with me. How I wisn that every child might be given a garden. Until I was a grown woman, mine was in a back yard in the City; though small, a source of great happiness. Now I have peach and pear trees,a tomato bed,lilac bushes, bridal wreath, burning bush, welgelias, honeysuckle,clematis, rose bushes and no end of flowers from seeds and plants that I put out each spring. And last, but not least, are the shade trees and a lawn which forms a gentle,sloping terrace to the side walls. It all started from a little, clty garden measuring about 18 inches square, on my fifth birthday."

-Its Evolution Including Different Types-

Although school gardening is practically in its infancy in America, the study of gardening originated many years before Christ when Cyrus the Great, Persian King, laid out gardens for the benefit of instructing the sons of noblemen in horticulture. Little is knows of the work for more than 2000 years. During the 16th. Century, botanical gardens were established by the Italian University and in almost a.1 the important Italian clties. Educators soon realized thoir 
importance and Comenius declared, "A school garden should be connected with every school where children can have the opportunities for leisure1y gazing upon trees,flowers and herbs and are taught to enjoy them."

One hundred years later, Rousseau in his "Bmile", lald great strese upon school gardens as a factor in education. Campo with his wards planted ten thousand trees. Salzman wrote, "School gardens have been laid out neither to draw the attention of passersby nor give great returns, but to instruct." Pestalozzi taught his pupils in both fieḷ and garden and said," I wish to make my estate the central point of my agrlcultural efforts." Froebel established gardens in all the large clties of Europe.

By royal edicts both Austria and Sweden, toox up the school garden movement. In Sweden, there are about five thousand. In Austria, accordIng to the Imperial school Law, enacted March $14 \mathrm{th}, 1869$, 1t was decreed that a garden for conducting agricultural experiment should be established in every rural school.

The Agricultural Soclety of Switzerland, not only encouraged but gives financial support to the movement. Here emphasis is placed upon the pedagogic and the utilitarian value of the school garden. The nature work is a part of the regulat curriculum. Its aim is pedagogical, the utilitarian information is incidental. In 1882, the sohools of France were reconstrueted and improved. A primary course has been outlined for the first instruction in agriculture and horticulture in which the pupils acquire some knowledge of soll, fertilization and field worx. In the upper grades the pupils are insuructed in theory and in practice. In 1887, a decree went forth that no school building in the Country to which the state contributes shall be accepted without a 
school garden be attached.

In Belgium, horticulture is compulsory. The teacher must be qualifled to give instruction, theoretical and practical in begetable culture. There esch elementary school must contain a garden measuring at least thirty-nine and one-half squared rods. .

It is conceded that the agricultural and horticultural progress of all Europe had its beginning in the school garden.

Berlin, sas a garden attached to each of her schools. In adaition, there is one central garden containing about ten acres. On regular distribution days,50,000 to 100,000 specimens are sent to school for biological and botanical study. The daily papers announce previously the kinds to be sent. Classes visit the garden to study the growing plants and trees. No unsightly spots here. There are vacant lots, divided into small plots apportioned out to.those who apply, including men, women and childrea. Use is made of every incis of ground. Those who have no gardens about their homes, have the opportunity of growing a few vegetables and flowers.

At Eirina, near Dresden Germany, there is a school yard with throe attractive summer houses, a small forest of native trees, an Alpine garden, a rockery and pond containing gold $f 1 s h, a l l$ work done by the pupils under supervision.

In a.l Europe, the fields and roadsides from village to village, the gardens everywhere, are marvels of beauty. The humblest cottage is surrounded by small fruits, such as Alpine stramberries, rappberries and currants. Where there is no space for a garden, a grapevine, an ivy or a wisteria is neatly trained over the front of the house. Planting in window boxes is another favorite way of gardening. 
In France, trises are grown on thatched roofs and on old but not unsightly tone fences. Wineyards are planted along the sides of the hills, no matter how steep they are. At Lausanne,Switzerland, close by Lac Leman, there are acres and acres of sloping ground covered witis carefuily planted grape vines. You wonder at the possibility of producing grapes ard are told that, arthough these grounds are terraced the soll that is washed down by the freshete and the rains is herolcally carried up again by the peasants on their baciks and putt in place again.

It has been thoroughly demonstrated that school gardens are considered an essential part of the educational system in all parte of. Europe, yet their introduction in the united States is of comparitively recent origin and nowhere regulated by law. But there are some in Ainerica who have given much valuable time in studying the movement, and in consequence a number of school gardens have been introduced in some of the larger cities of our Country.

\section{-Our Pleneer School Gardens-}

Of the pioneers, Boston tares the lead, supported by the Outedr Art Association and the Massachusetts Civio League. A school of horticulture was established in Hartford,Conn.by the Rev.Francis Goodwin in 1900 , to give opportunity for individual work and graded training for the boys of the Watikinson Farm School. When Mr.Hemenway took charge the work was considerably broadened, including boys and girls from the City, teachers' classes and gardens for adults.

Another pioneer, model garden is that of Dellitt Clinton Park School Farm of New York, begun in 1901, by Mrs. Henry Parsons. Here each child had a plot, four feet by eight feet. By planting two crops, 
one in May, the other in July, a thousand childrea, who otherwise would have to grow up in the streets, were given occupation. Schools and visiting classes were supplied with nature study material. Cripples were taken to bask in the sunshine and allowed to spend some pleasant hours working in their individual plots. To appreciate the good accomplished in this garden one should see 1t. There is nothing like it in the entire neighborhood. It is the salvation of the children in this crowded tehement distriet.

\section{-Model Gardens Up To Date-}

The sohool gardens at Yonkers,N.Y.,Philadelphia, Pa., the graded work at Washington and Cleveland, take the lead and give to these cities the preatige of being the only ones in which the Boards of Education fully realize from an educational standpoint, the value of the school garden. In each City, there is a supervisor to whom is given authority and suitable appeopriations fornthe work. The district of Columbia has a Congressional appropriation of \$1200. for school gardens and appoints Miss Susan Sipe, one of the teachers at the Normal School at a nominal sum as supervisor of Nature study and School Gardens. There the work is so systematized that a certain amount of gardening is required, just as necessary as reading, aritumetie, drawing and other branches.

Washington has four large school gardens on vacant lots. In addition one hundred school grounds for white children and fifty for colored children are decorated. The children have had some part In the planting and care of all but three of these. Miss Susan Sipe nas also been appolinted Collaborator in the Bureau of Plant Industry and is furnished with a green house for the instruction of Normat 
students. The Department of Agriculture and Bureau of Industry work together,furnishing the supervisor with plants, seeds and other material.

At present the school garden work has so grown in importanee that a school garden Department has been established with fir.Dick J. Crosby at the head. Many bulletins for teachers have been 1 ssued and read by thousands. The thrée most called for aro,No.195 Annual Flowering Plants, No.218, The School Garden, and No.134 Treo Planting on Rural School Grounds. No.204,Gardening and Nature Study in English Schools,written by Miss Suisan sipe after a visit to England, is an unusualiy interesting bulletin.

-History of The Work In Loulsville-

School Gardening here is no longer in 1ts infancy. If there is one thing of wnich we are truiy proud,1t is the steady growth of this work increasing in vaiue each year, unt1l at present wherever space w11 permit of a garden, one is made. For some years, there have been window gardens at several schools for decoration as well as study. W1th nothing but a small grass plot in the front yard at the Normal School an experimental garden was conducted in 1899 , in a back yard three suqares away.

Bleven children formed a thoroughly wide awaxe organlzation, and called themselves, "The Gardners' Club." Here the children worked all vacation raising flowers as weil as vegetables. They received instruction in soll propration, planting, transplanting, cultivating, watering and weeding. One boy who never could be persuaded to eat a tomato, ate the one he raised,declaring it was the best thing he had 
ever eaten. One frosty afternoon, at the ond of the season a party was given the children where the com they raised was popped over a grate fire. Tnere was enougin for $a 11$ and some to be taken home. This was the first school, garden in Loulsvilie and the beginning of a movement which has since sptead over the Gitire City, not only for the care and beautifying of the premises, but in some schools for instruction leading to the managing of gardens at home.

So successful was this venture that there was an earnest desire to have a garden for the planting of. vegetables at the Normal School. But this yard was paved as most sohool yards were at that time.

This did not dampen the ardor of those interested. The bricks were removed and good soll and street sweoping hauled in by the boys who became quite enthusiastic about the worz. Th1s garden measured seventeen feet by twenty-five feet and contained twelve small plots, one for each class, from the Kindergarten up through the grades,including the Normal classes.

In order to improve the general appearanee of the entire yard, without restricting the playground, two feet of bricks and gravel all along the fence in the girla' yard were removed. The stone along the fence in the boys' yard prevented any gardening, but the boys have the same privilegesas the girls in the garden which they helped to make. In four months the fence was entirely covered with maderia, balaam and cinnamon vines, to which three varieties of clematis, honeysucklo ramblers, English and Boston Ivy have been added. From the woods the children brought oross-vine, trumpet creeper and Virginia creeper, for fence coverings. In the border were placed coreposis, shasta daisy, several varietios of 1 ris and such shruive as Rose of Sharon, 
uardy Sunflower, welgelia, burning busis, hardy hydrangea, flowering almond, mock orange and golden bell. Not the least interesting is the wild flower garden; the plants therein contained were a gift from the children of Berea College to the kindergarten of Loulsville. The Norma1. School garden being consldered the best place for them, the wild flowers were sent there. Since that the older children have added buttercups, May apples,bluets, wild ginger,wild popples and anemones, which they found in the woods on their field trips.

Work was begun by planting shrubs. In the border along the house and Iron fence in the front yard. Gradually more were added,filling in with low, hardy plants and edging with hundreds of narcisei, tulips and hyacinths. When the snow nas just abott disappeared, there appear the crocuses, followed in quick succession by daffodils, hyacinths, flowering almonds, burning bush, tulips, opireas and all the lovely Irises. Then the coreppsis with its blooms of pure gold. Golden glow and the lilies hold forth during the summer. In September, 11veforever is in its glory, while as late as Ootober, the Maximilian Sunflower is gorgeous with bloow, single stalks bearing as many as fortyfive little sunflowers.

Seeing all this stimulated the children to still greater effort. They enfoyed working a garden which gave them so much pleasure. Here the children learn the A.B.C. of landscape gardening. Straight lines were avoided, space was left open, the lawa smooth and the shrubbery planted in masses.

Vandallsm which makes the pursuit of horticulture almost impossible in many neighborioods, was totally unheard of. Not a flowers has been touched, not even the exquisite hyacinths, white, porcelain blue, 
and royal purple which bloomed so temptirigly at Easter time.

The front gate is never locked. The children have learned the lesson of private care of public property. Instead of being a nuiance, these children have been a boon to the neighborhood.

By the operation of the Superintendent of School and the financlal support of the Commercial Club and Board of Education, many yards have been Improved, school gardens belng ibtroduced during the last four years in about thirty yards.

One of the most successful initial attempts at school gardening repoted by the teachers, was carried on by the Portland School. Tnree hundred and seventy-five plants donated by the Park Commissionwere distributed among sixteen schools. Those sent.to Portland in the Fall of 1902,kept the windows gay for weeks with their wright flowers. As the season advanced the plants were carried into the basement over night, but in very cold weather this plan became impracticable. Each teacher then called for volunteers to take the plants home and care for them till Spring. Occasionally tnrough the cold winter months there came a sorrowful report of a frozen plant, but more of ten a record of a new bloom on a geranium, or two new leaves on a begonia revealed the interest with which the plants were watched. With the first warm days of spring the plants were returned.

Some begged to keep the plants they had learned to love. On visiting one home, where the front room served as a tallor shop and living room, a blooming gerantum brought by the child from school was the only brightspot in the room. It was decided that the plant stay there and another be purchased for the school garden; 
Another boy proudly stated that he had taken nine slips from his plant during his possession of it.The children's enthusiasm was sucn that the faculty decided to purchase tools. The little plot in front of the school house became transformed into bower of loveliness Later twelve dollars and twenty-five cents which had been realized from the sale of beans from this garden, was invested in indoor art for the school room.

Inspiring was the success of the George Rogers Clark School, where a clay bank was converted into a beautiful park onclosed by a California privet nedge. In the Ball was held a splendid exhibit of plants raised in the school room, in the school yard and in the home gardens by the children and grown up in which all Crescent Hill became enthusiastic. Prizes were distributed. A wonderful impetus was given to children and to the civic betterment of this beautiful suburb. In consequence the railway right of way was beautified by roses and shrubs.

One can find no more attractive terminal than this, with its beautiful foliage and lovely flowers unsurpassed by any all along the road from here to New York.

At the Walnut Streot School, the bricks in the small front yard were removed, a lawn made, a hedge and flowers planted. The boys became intérested. Window boxes were made and filled.

The J.B.Atxinson Sohool had a tullp bed second to none. The transformation of the yard at Braok and Fentucky, with its thousand bulbs,its fence removed,its lawn instead of bricks,1ts shade trees, was almost beyond bellef. All this was the work of the children,under the able supervision of the Principal of the school. Each school had 
its own problem.

Looking at the bricks and uninviting yard at one of our schools, a. Mother said,"I am not surprised that boys play truant here. 'Tis a wonder that more don't do it."

In order to stimulate the children, ofroulars containing a list of seeds at one cent per packet and definite instructions for planting .

-As Introducing Simple, Real and Useful

Forms of Nature Study-

Gardening in itself is of the greatest value in the education of children,but it does not perform its proper function unless it has some organic connection with the other work. At the Normal School before planting soll formation was studied in the geography class. The children were taren to a quarry and to a sand ptt. They learned that water, air and sun, pulverized rock, that there could be no soll witnout rocz, and the utter dependence upon rocks of animal and plant 11fe. Soll suould be treated for 1 ts chemtcal and physical properties. The preparation of the soll can be converted into a lesson on soll physics. The nature of the soll as a source of plant food, as a mechan1cal support to the plant and as a store house and conveyor of water and air, should be impressed.

Here in the school garden the children leam that tiough the seeds be the best, the lignt relation most favorable, the water supply sufficient, if the soil is in poor oondition the plants will sicken and die.

Of prime importance is knowing how to treat the soli. The ground 
must be properly spaded, turned over, raked and pulverized. Well rotted manure or sweepings from a blacksmith shop must be worked in. When no other fertilizer is avallable, street sweepings have been succossfully used.

By actual experiment, children learn that fine mellow soll will retain motsture and enable the roots to get the food; that soil is a pantry from which the hungry plants draw their nourishment by means of the fine root hairs. Many soild are poor and contain little nourishment, but it is amazing to think of soils full of the necessary plant food, but so locked up that it is not avallable.

\section{-What Is Plant Food\%-}

Many chemicals constitute plant food, the most important of which are three;nitrogen, potassium and phosphorus salts. Is the follage Iine,green and abundant? The children learn that there is plenty of nitrogen, Now appears a well formed flower. This tells us that potash 1s available. Good, sound fruit has been fed with potas. and phosphorus If the plant looks sickly, you can be sure it noeds nitrogen. If there is trouble with flowers and fruits, potash and phosphorus are needed. The real key to the food question has to do with the bacteria, good and bad. The good ones act on the soll particles, changing them into food which the plant can use. The bad ones prevent this. To encourage the good, the best conditions must prevail:-

(1) Plenty of water

(2) Sufficient air

(3) Proper condition of the soll.

If the soil is wet and cold in early spring causing it to bake. and crack, you cam be sure it contains too much clay. Add some sand, and a fertilizer which improves the soil physicaliy by making it more 
friable and chemically by storing it with rich nitrogen. We learn by ectual test that sand has bad habits,too. The soll particles are so far apart, that the water filters through leaving it hot and dry in the sun. Manure will correct this. Commercial fertilizers can also be cautlously used.

In your indoor labratory work, observe monocotyledons, dicotyledons. Note where the seed leaves are after planting, where food is stored in the different seeds, how the leaves are formed and manner of growth of bean, pea, corn, squash and morning glory.

If practical, the children should be allowed to do all the work of preparing the soll in the fall, in the spring, the planting of seeds and care of the plants. Seeds snould be tested and germinated,precentage noted, thus avolding a waste of time and energy in a second planting. -Planning And Planting The Garden-

Plan your garden on paper first. The economical use of the area at one's disposal is quite as important as successful planting. In a vegetable garden plant radishes and lettuce, following these quickgrowing crops with beans and tomatoes. A third planting of winter onions could follow. This rotation provides for a continuous use of the land and the growing of several crops. Thus the childron learn their first lesson in intensive gardening. -Flowers= Annuals, Blennials and Perennials-

"Plants are the missionaries of nature, constantly at wori attempting to cover some ugly scar which civilized man has made in his struggle to wrest from the earth the living wilch he claims that she owes him. "If you will but give nature the euggestion of your wishes she will paint for you the rich shade of the phlox and the dianthus 
pinks; she will carpet your floor with a velvet rug of green and strew upon it the stars-the dandelions.

While shrubs and trees are needed for a frame work in the adornment of a place,vines, grass and flowers give finish anc completeness to the picture. Tall grwolng annuals such as castor bean, sunflower, cosmos and flowering sage may be used as substitutes until the snruivery has growa to sufficient size, to command the situation. These cover fences and serve as temporary soreens for inattractive sheds and bulldings.

Rapidly growing vines, moon flowers, morning glories or oypress can be used for training over fences or shading porches. Planting must be done in a syatematio, orderly manner. There is a great morai force in a straight line. Children are apt to plant seeds too close and too deep. Carefully thin out and transplant.

Devote a small plot of ground to food plants, as wheat, rye, oats buctwheat and peanuts; to ftbrous plants as flax, hemp cotton; to medical plants, as digitalis, lobelia, liverwort, dandelion, mullein; and to herbs as rosemary, thyme, marforam, dill, fennel, sage and lavender.

Watering and coneerving moisture are important and should receive some attention. Capillarity of the soll should be taught after a rain or a sprinkle, when the surface is dry, chlldren should be taught to go over it with a rake, trowel, onion weeder, or a sharp sticl for the want of a botter tool, breaking up the surface of the soll, forming a soli mulcn, thus lessening capillarity. The water is drawn near the surface when it is neoded by the roots of the plants but cannot escape into the alr by evaporation. 
-Our Native Flora-

Most people are very igoorant of the wealth of our native flora. A garden of wild flowers arranged according to systematic classification, affords opportunities for valuable instruction, inculcates an apprectation for the rare and fast disappearing species and engenders a feeling of protection and stewardship. Children should be taken to the woods, but the wholesale removal of plants should be discouraged In a garden there should be squirrel, corn, saxifrage, dutchman's breeches, larisspur, buttercups, wild ginger, wild poppies, bluets, anemones, wood ferms, May apples,trilliums, Virginia creeper, crossvine and others growing in the vicinity.

It is neither possible nor advisable to introduce all varietios Into the school garden, for conditions are so unnatural they could not live and many resent being taken from their native haunts. The wise thing is to select species which are tolerant of poor conditions and try to improve them under cultivation.

-Hydrophytic, Mesophytic and xerophytic plants-

Note the different conditions under which these grow. Observe whether hydropnytic, mesophytic or xerophytic. Classify them. On a rockery, grow live-forever, many varieties of cacti and saxifragas which prefer xerophytic areas. Let the children observe how well they thrive with comparitively little water. Note how they stand the drought when the other plants succumb.

Splendid botannical gardens of this kind exist in Germany, perhaps the finest is found at Sixt near Geneva, Switzerland. Here can be found every conceivable Alpine flower, edelwels, many varleties of wild pansies,pinks, Alpine violets and hundreds of others from the 
Pyrenees, Jura, Savoy and Alps Mountains. All are properly labeled.

Most lessons relating to adaptation of structure to function can best be given with wild flowers. Simple experiments in plant physiology and ecology can be carried by the children. The relation of leaves to catching and shedding rainfall, arrangement and form of leaves in relation to lient;modification of leaves and stems for purposes of support;movement of leaves as a protection against heat and cold;color form, marking of flowers for the attraction of insects for the purpose of cross-pollination, these and more studies of vital importance will make the wild flower garden highly instructive.

Note the damp, rich, loamy soil preferred by the ferms, which grow west in the shade. Observe those plants that grow in the same kind of soli,but prefer a sunny situation.

Grow water hyacinth, duckweed and umbrella plant for the study of hydrophytic plants. Observe where willows, sycamore and water birch are found. Transplant peppermint and water cress, pond 1111 es and sagiteara, if a suitable place can be mado.

-Tne Nursery Forest-

The transpiration of molsture by the plants is one of the ciauses of rainfall and of the changes in temperature. The elements of forestry can be taugnt in connection with trees in the arboretum. Seeds of the maple, oak, ginkgo,elm, tulip and magnolla for shade and ornamental trees, grow readily in the school garden, where as experiments can be easily made with tiose of the apricot, peacis, apple, pear, cherry and other fruits.

In view of the fact that the vitality of tree seed varies from one to nine tears, the children lears that the seeds of maples,elms, 
poplars and willows, should be planted soon after maturity as their seeds have the shortest duration of 11fe. The hickory nuts,acorn, chestnuts and buckeyes, scarcely survive a season.

The seeds of the leguminosae locusts, such as yellowwood, coffee tree and red bud nave the longest period of vitality.

Problems in forestry are now confronting our people and our citizens are seeking information which will enable them to act wisely in deciding these momentous questions.

The Thuringian and Black Forest of Germany, perhaps, best show how forestry can be successfully earried on. There are acres of young tender seedlings, some six inches tall, others one foot tall, and so on until you come to vast stretches of the mature firs.

The cause of our floods along the Ohio, for instance, should be taugint the children. The teacher may instruct the pupils in her geography class, that these floods are due to the removal of the forests from the Appalachian buntains, and if this work of forest destruction continues the floods may become worse. Do not tell the children bare, external facts. They were better left unsaid, but lead them to make observations for themselves, thereby learning the influence of forests upon stream flow.

In these garden studies, the children should be encouraged to observe the school grounds and their own back yards; to see what vecomes of rain and snow water, how exposed soil is washed and gullied and whether the muddy little torrents transport thotr burdens, how various kinds of plant growth modify these effects; how gently the rain falls, JW slowly the snow melts, and how absorptive is the forest soil-all 
questions of tremendous importance concerning erosion.

The children stould learm the economic value of our treos. That we must grow trees for furniture, building purposes, railroad ties, tools and farm implements. That every time one is cut down, two siould be planted in its place. This is the lesson Germany teacios, where re-foresting is constantly boing carried on.

\section{- Tindor Gardening-}

Thts has successfully been carried on in some places, demonstrating that this form of gardening can be carried on where outdoor space is wanting. Make the boxes to fit the window, not to exceod six inches in depth. Ths best soil is a compost of turfy loam.

Asparagus, sprengeri a drooping variety is ornamental and especially adapted to window gardening.

The Eoston fern is one of the most satisfactory plants for this purpose. The Rex begonia is beautiful in form and color and texture of foliage. Wandering jew fills in and hangs over the box. The many varieties of begonias endure shade and are very decorative. It is better to buy good plants that will increase in beauty than cheap ones which will soon have to be discarded.

A box of nothing but English ivy is most attractive both summer and winter, and requires perhaps less care than any other.

Scattered here and there by planting Sclilas, crocuses, daffodils, tulips and hyacinths these will be one succession of color from December until March.

-The Hot Bod-

A hot bed three feet square would accommodate several hundred 
California privet hedge slips which planted in the fall would be ready for transplanting in the spring. Much to the delight of the children at the Normal Schoo, Ledge plants which they distributed in the neighvorhood were successfuily raised in the hot bed at school.

English and Boston ivy can easily be started in a hot bed, alse seeds of choice plants, such as pansies,asters, dianthus pinks and carnations.

The hot bed is made by using fermenting stable manure preferably that with a small amount of straw or litter in it to the depth of one foot. Above it place beamy soil, on top sharp sand. A frame eighteen inches in the back and eight inches in front should be used, an ordinary window sash will suffice. Use a board covering or an old carpet for extra covering in severe weather. Water in the morning if necessary rather that at night so as not to reduce the temperature by letting out the heat.

-Garden Ennemies And Friends-

The children find that man insects attacis the plants. The tussock moth can easily be found on maple trees. Many of these were hand picked by children at the Normal School last year. Eggs were counted and destroyed during the winter, so were many bagworms.

The tent Caterpillar is responsible for the unsightly webs wilch are common in spring as are those of the fall web woria.

The click beetlo's acrobatic feats are known to many boys and girls who do not realize that he spends part of his life in the ground as a yellow worm.

The Cicada has a life history full of interest to children. They are all familiar with the peculiar shrill nolse made by the male by 
means of two drums on the underside of the body. The discarded nymph sxins may be found clinging to fences and to the trunks of trees. To watch it emerge from its nymph skin, to observe how the female with its iviposter cuts slits in the bark of the twigs in which to deposit eggs is most interesting. It remains in the ground sucking juices from the plants as does the oicada Septemdecim, its near relative which retire to the earth for seventeen years and is commonly called the seventeed year locust. How to combat these and hold them in checl should be the lesson here.

Close observation of the lady-bug will reveal that she is ia search of aphids or plant lice, which are so destructive. Associated witn the lady bugs are the black ants. These have discovered that by stroking aphids with their antennae, the tiring insects give out drops of honey dew, which the ants devour greedily. They have become as fond of it that they guard the aphids,also protect their eggs over winter, carrying the young to new pastures as soon as they are hatched out. Children snould be taught not to harm the spider. By close observation they will see it destroy mosquitoes and flies.

The toad one of our best garden friends, rids the garden of slugs, pill bugs and other tiny, inarmful animals. The eggs may be secured in early spring and the tadpoles can be kept in the aquarium at sohool for daily observation. Frogs and toads both render great service in the garden and are wonderfully adapted by nature in the etructure of the tongue for the work they do.

The house fly, about which so much has been said of late can be greatly checked by a war on filth. Absolute cleanliness in the house 
and about door yards will control it. In addition, a weak solution of formalin will kill it.

Too little is known of both harmful and beneficial insects and animals. Only a careful study of these will prove most educative. To combat garden enemies most effeotually, it is necessary to nave a knowledge of their life historles.

\section{-Birds-}

If insects deatroyed were allowed to live, they would have countless millions of descendents, Were 1 t not for the birds we can safely say there would be no plant lifo.

Hawks and Owls rid us, of the rats,Fly-catchers, kingbirds, pewees, phoebes.capture their prey on the wing. Woodpeckers, chickadeos, nuthatches and creepers explore the bark of trees for egss,gruivs and ants and render good service to fruit growers and gardners.

The thrush family-robins, bluebirds, wilson hermit and olive backed thrush, prey upon grasshoppers, crickets, beetles, caterpillars, spiders and cutworms.

The yellow and black billed orickoos are very valuable to the gardner in destroying the larvae of moths and butterflies. Their food consists of hairy caterpillars,tent caterpillars, fall web worm, tussock worm and many others, the worstof the plant enemies.

The Balitmore orlole is one of our most attractive and beneficial birds, its food consisting of hairy caterpillars and plant lice. The cedar waxwing, catbird and robin are fond of cherries and small fruits preferring the wild to the cultivated varieties. In the stomach of three mouming doves were found 23,100 weed seeds. Think what such birds as these mean to our Country Millions of dollars could 
be saved. Is there a farmer in the land who would not welcome as a friend the man who would offer to uproot and kill 23,100 weeds?

-Weeds - Bold Robvers of The Soll-

"The most human plants after all are the weeds. How they cling to man and follow him around the world. How they crowd around his barns and dwelling, throng his garden, jostle and override each other." Some have food values not to be despised, such as dandelion and hullein. As a pot herb also may be used that pest $6 f$ the garden, purslane or "pussly". An Eighteentr Century writer speaks of it as being "little inferior to the asparagus".

We relish kale, lettuce, spinaen, beet tops and swisschard as greens, but question the use of the pig weed whose tender shoots are as much sought for food in some sections of our Country as were the young branchlets of the common nettle which the early Colonista boiled for pot nerbs.

Weeds in some places are cultivated. For instance, mullein in England is planted in the greenhouses and is called the American velvet plant.

Weeds are excellent irom an aesthetic point of view. In nature'e plan they cover many a waste place and "there is a touch of grim satire In their luxuriance, as if the rough muse were bidding man discover how rich the earth for his own use, how costly his neglect to reap such wealth."

Weeds have their economic value. The despised ragweed,for example,holds to seeds until the birds in winter need them to satisfy their hunger.

But coming to the school garden to find the dock, ragweed, spanish 
needle and purslane stealing the food intended for the plant we have been so tenderly nursing, banishes all their uses from our minds. Children may be fond of the ox-eyed daisy and black-oyed Susan, but we must confess that these are among the farmer's worst enemies along with wild mustard, cocklebur, plantain and Queen Anne's 1ace. Every country boy knows the milk weed with its juicy stem, spilling milk at every break and its boat like seod pods, laden witn precious silk of finest tissue. Is there any. weed more difficult to eradicate?

In the garden soil there are layers and layers of weed seeds. Says John Burroughs, "As I uncover the earth in my fields ragweed and pigweed spring up; if these are destroyed,honest grass, quack grass or purslane appears; the space or plow that turns these unfer is sure to turn up some other variety as chickweed, sheep sorrel or goose foot. There is a rank growing Jimson weed found on aimost every vacant lot. These and many others threaten our garden kingdom. The best and safest remedy against weeds is frequent cultivation.

Our garden intimately related to us personally presents quite a contrast to the teaching about tadpoles one day, milkweed pods another and bees still another, as abstract subjects. The brown beetle that flies about our windows and screen door at night, apparently harmiess comes from the grub which eats the tender roots of our garden plants. The bee gathering nectar from the iris, dusting his legs on the pistil of another iris,fortilizes the flower and seeds which can be successfully grown and formed.

The earthworm is a living plow, loosening up the soil as it burrows underground, helps cultivate the garden soil and prepares plant food. These are all intensely interesting because they live in our garden when the growth of our plants demands constant care, cultivation 
and warfare against enemies.

-Garden Studies As Correlated witis Art,

Language, Mathematics and Literature,-

Many are the opportunities for correlation in school garden work. The very. first essential in easy writing is to have something to say, as original subjects are hard at best. Let the children write about the toad in the garder, the bogworm or the tomato worm. If the child has had no such experience, why not begin by assigning him a living topic. Let him make observations and report in writing. Correlation of gardening with art gives excellent results. The child draws that in which he is intensely interested. The radishes he raised are of great moment to him. These drawings can be further applied in design for book covers and in varlous other ways.

The child should draw to a scale the entire garden, his owr plot or class plot. The depth of planting, the distance apart, distance of rows, number of plants in one fort, one row, more rows, the market value of products and many other problems will present themselves in Mathematics. When the problems are worked out they should state a fact worth knowing.

In the manual work, stakes, labels, rustic baskets, markers, garden benches, bird houses, bird baths and many other useful things are made.

No bettor work in Geography can be givem than the study of erosion.

In the study of gardening there should be a course in English poetry. The poems should be exactly appropriate to the subject and the occasion. Much excelient poetry for Arbor and Bird Day, for spring, winter and the other seasons adapted to the grade.. 
" A school yard planted by a gardner is good if the woric can be done in no other way, but the one that best serves its educational value, is planted by children, no matter how small the ground or how crude the result. It is in such a garden that moral teaching is accomplished."

All grounds can be made more attractive. In fact, such improvement is of prime consideration. It makes the progress of the school in pedagogical ideas.

The school garden should have a special area set aside for 1 , as any other labratory has. It should be ormamental as well as useful. It should be a good one to do its best work. It is for direct instruetion and a capable director should be in charge. It should relate the child's school life to his real ilfe.

\section{-Benefits Derived From School Gardening-}

Here the children learn some necessary civie virtues;private care of public property, economy, application, concentration, thrift, honesty, Justice, industry. They also learn what is porally as well as culturally right in the garden. Lessons like these become gradually ingrained habits of tnought and the child fibre is toughened morally. In a word,it makes better citizens of them and if there is one thing more than anything else it is good citizens.

As for sanitation, cleanliness goes hand in hand with the planting of trees and flowers. As for health,gardening expands the the lungs, enlarges the chest, develops the muscles and deepens the breathing.

It has made plants a part of the home as books and pictures are. Not only do they appeal to the owner but to others. It has awakened an 
intrinsic interest in natural objects towards conservation. Here the children have come to feel that every plant and animal lives its owa life. It has its battles to fight.

The garden is an excellent place to learn the difference between true ana false economy. Actual money is not the only thing that can be spent wastefully in a garden, but also energy, labor, time, seeds, water, air and fertilizer. The proper instruction in school gardening leads to more inteligent use of time and strength in every task in life. Every child needs to be taught how to save time, labor and material in daily tasks. The application is made in all things. The children are taught to think about work, the best way of doing it, and then to make the efficient way a habit.

The children note the difference between the strong, healthy plants grown in the sunlight and the pale delicate ones grown in the shade.

Their attention should be called to the fact that people who work in factories or in the house, to those who seldom go out in the fresh air and sunshine, arousually without the ruddy color of the former or those who spend much time out of doors.

In removing the cover gradually from plants grown in the dark, observe, the noxious insects and other pests gathered there. This is another great lesson that much disease and many insect pests thrive in semi darkness. Call the children's attention to the fact that almost all the germs of our serious diseases can be rilled by sunlight. 